\title{
URGENCY OF MEDIA BASED LEARNING ENTREPRENEURSHIP IN PRIMARY LEVEL
}

\author{
Yulianti dan Hartatik \\ Universitas Kanjuruhan Malang
}

\begin{abstract}
Abstrak
Media pembelajaran sebagai alat untuk mengantarkan kemampuan siswa dalam mengapresiasikan sejumlah kemampuan, pengetahuan dan sikapnya dalam menyelesaikan permasalahan sehari-hari dalam proses pembelajaran. Setiap anak memiliki kemampuan yang bervariasi dalam belajar. Hal ini karena latar belakang siswa akibat adanya faktor internal maupun eksternal penyebab kendala anak belajar. Sebagai contoh ada beberapa anak kesulitan untukbisa konsentrasi dalam belajar karena faktor keturunan yaitu keterbelakangan mental orang tuanya sehingga dimungkinkan dapat mempengaruhi totalitas belajar siswa. Selain itu, tuntutan keluarga secara psikologis juga kekurangan gizi nutrisi makanan juga akan mempengaruhi belajar anak. Dan yang menjadi prioritas kegagalan pelaksanaan pembelajaran karena guru atau tenaga pendidik kurang memaksimalkan menggunakan media pembelajaran sebagai alat untuk melatih dan mengasah kemampuan kewirausahaan, yang nantinya dapat memberi wawasan kemandirian siswa dalam terjun di masyarakat nanti. Pada masa modern ini sangat dibutuhkan media pembelajaran yang dapat mengantarkan pemahaman anak dalam menyelesaikan masalah-masalah dalam proses pembelajaran baik di kelas, di rumah maupun di mana mereka beraktivitas nantinya, sebagai salah satu alternatif media yang digunakan adalah media berbasis entreprenership. Media ini menawarkan bagaimana siswa bisa melatih tanggung jawab diri, kemandirian menanggung resiko, punya komitmen tinggi untuk mengejar cita-citanya. Harapannya anak-anak sekolah dasar tidak hanya mampu dalam pengetahuan kognitif saja akan tetapi mereka dapat memiliki kemampuan dan sikap yang baik dan siap menyongsong masa depannya di masa depan nanti.
\end{abstract}

\section{Kata Kunci: Media Based Learning Entrepreneurship}

Pembelajaran merupakan bagian dari pendidikan (Sagala, 2010:5) yaitu suatu usaha sadar yang direncanakan dengan matang, mantap, jelas, dan lengkap, menyeluruh, rasional, dan objektif menjadikan peserta didik menjadi warga negara yang baik. Harapannya dengan pembelajaran yang baik akan memerikan pengertian bagi peserta didik terkait pentingnya melakukan kegiatan belajar untuk kepuasan dan kebutuhan dirinya untuk memperoleh ilmu pengetahuan dan keterampilan sebagai modal hidupnya kelak jika telah dewasa.

Bentuk pembelajaran dapat terjadi sewaktu-waktu, selain pembelajaran yang terjadi di sekolah formal juga terjadi di lingkungan rumah anak-anak baik di lembaga non formal maupun informal.

Dengan demikian, kegiatan belajar siswa dapat terjadi bila siswa ada perhatian dan dorongan terhadap stimulus belajar. Proses interaksi peserta didik dengan pendidik dan sumber belajar pada suatu lingkungan belajar merupakan bentuk tanggung jawab yang diberikan pendidik agar dapat terjadi proses perolehan ilmu dan pengetahuan, penguasaan kemahiran dan tabiat, serta pembentukan sikap dan kepercayaan pada peserta didik. Dengan kata lain, pembelajaran adalah proses untuk membantu peserta didik agar dapat belajar dengan baik.

Berdasarkan hasil penelitian Yulianti (2014) tentang model dan perancangan kantin jujur berbasis entrepreneurship ditemukan bahwa kantin dapat sebagai salah satu media pembelajaran anak sekolah dasar (SD). Hal ini dapat dilihat dari suasana keaktivan siswa di dalam kantin, siswa ketika dilibatkan dalam petugas piket maka mereka secara langsung 
mengalami bagaimana mempersiapkan, melaksanakan penjualan sampai membuat laporan.

Usia siswa Sekolah Dasar berkisar antara 6-12 tahun. Masa ini merupakan "masa sekolah". Pada masa ini anak sudah matang untuk belajar atau sekolah. Disebut masa sekolah karena dia telah menyelesaikan tahap pra-sekolahnya yaitu taman kanak-kanak. Penetapan batas antara usia pra-sekolah dengan usia sekolah sebenamya tidak mempunyai dasar psikologis yang cukup kuat. Berbagai studi menunjukkan bahwa usia pra-sekolah yang ditandai dengan kegiatan bermain masih akan berlanjut terussampai anak berusia sekitar delapan tahun (sekitar kelas 3 SD). Pada masa pra-sekolah sampai dengan usia sekitar 8 tahun tekanan belajar lebih difokuskan pada "bermain sambil belajar", sedangkan pada masa sekolah dasar aspek intelektualitas sudah mulai ditekankan.

Usia 7 sampai 11 atau 12 tahun termasuk dalam tahapan periods operasional konkret. Pada periode ini anak memiliki kemampuan mengklasifikasikan angka-angka atau bilangan. Mulai mengkonservasikan pengetahuan tertentu, kemampuan proses berfikir untuk mengoperasikan kaidah-kaidah logika meskipun masih terikat dengan objekobjek yang bersifat terikat. Fase ini menurut Piaget, seorang psikolog anak, menunjukan suatu reorganisasi dalam stniktur mental anak. Dalam banyak hal pengajaran di Sekolah Dasar dapat dikatakan sesuai dengan perkembangan kognitif para murid. Bila sekolah memperhatikan keterampilan dan aktivitas seperti menghitung, membentuk, dan sebagainya maka itu membantu perkembangan kognitif. Karyawisata ke objek-objek seiarah, ilmu pengetahuan alam melalui percobaan dan melakukan sendiri, menambah kesempatan perkembangan kognitif. Aktivitas anak pada fase ini dapat dibentuk dengan peraturanperaturan, karena hal itu mempunyai nilai fungsional.

Dari penjelasan di atas maka pentingnya media pembelajaran berbasis entrepreneurship di tingkat SD.

\section{PEMBAHASAN}

\section{Pengertian Media Pembelajaran}

Kata media berasal dari bahasa Latin"medius" yang secara secara harfiah dapat diartikan sebagai perantara atau pengantar. Media dalam proses pembelajaran merujuk pada perantara atau pengantar sumber pesan dengan penerima pesan, merangsang pikiran, perasaan, perhatian dan kemauan sehingga terdorong serta terlibat dalam pembelajaran. Proses pembelajaran pada dasarnya juga merupakan proses komunikasi, sehingga media yang digunakan dalam pembelajaran disebut media pembelajaran.

Mengatasi berbagai problema dalam pelaksanaan pendidikan karakter peserta didik Sekolah Dasar (SD), dibutuhkan sarana atau media pembelajaran yang mengesankan dengan model-model pembelajaran menarik, salah satu model pembelajaran yang dilakukan di luar kelas yaitu model pembelajaran kooperatif dengan metode demonstrasi, bermain peran (roll playing), ataupun metode inquiri dan metodemetode outbond atau out door yang ditunjukkan oleh para peserta didik di kantin sekolah. Dalam ruang kantin tersebut peserta didik secara langsung di latih sikap seperti; kejujuran, kesabaran, kerjasama, disiplin, belajar menghormati dan menghargai orang lain, cinta damai, kebersamaan, menjaga kerukunan, belajar bertransaksi, tanggung jawab, dan karakter yang lain-lainnya (Yulianti, 2014: 23).

Penanaman nilai-nilai kejujuran melalui kantin kejujuran merupakan model pembelajaran simulasi sosial. Model pembelajaran ini menganggap peserta didik (pembelajar) sebagai suatu sistem yang dapat mengendalikan umpan balik sendiri (self regulated feadback). Sistem kendali umpan balik ini mempunyai tiga fungsi, antara lain: 1). Menghasilkan tindakan sistem terhadap target yang diinginkan (untuk mencapai tujuan tertentu yang diinginkan). 2). Membandingkan dampak dari tindakannya tersebut, apakah sesuai atau tidak dengan rencana yang seharusnya (mendeteksi kesalahan). 3). Memanfaatkan kesalahan untuk mengarahkan kembali ke arah/ jalur yang seharusnya (Uno: 2010: 28).

Dengan demikian dapat dikatakan kantin kejujuran di sekolah dapat dijadikan sebagai 
salah satu media pembelajaran alternatif untuk melatih siswa berjiwa entrepreneurship sejak usia dasar. Karena dalam kegiatan di kantin siswa akan belajar secara langsung bagaimana mempersiapkan menu makanan sampai pada membuat laporan akhir setelah pelaksanaan penjualan di kantin sekolah. Dengan melatih pembiasaan siswa di kantin dapat memupuk jiwa entreprener ketika mereka sudah terjun di masyarakat nantinya.

\section{Entrepreneurship}

Kata Entrepreneurship sebagai terjemahan dari kata "kewirausahaan/ kewiraswastaan" (Herawaty, 1998). Dalam bahasa Prancis, arti Entrepreneur berarti between taker atau go-between yang bila diterjemahkan ke dalam bahasa Inggris Entrepreneurship menjadi "to undertake". Istilah Entrepreneurship dilansir pertama kali pada tahun 1755 oleh Richard Cantillon yang waktu itu sedang melakukan penelitian tentang IQ wirausahawan. Untuk selanjudnya, istilah entrepreneur lebih dipakai daripada wiraswasta atau wirausaha karena sudah menjadi istilah internasional (Astamoen, 2008).

Enterpreneurship merupakan hal yang lebih merujuk kepada kepribadian dan semangat tertentu, yaitu pribadi yang mulia, kemandirian, inovasi, pengambilan keputusan dan penerapan tujuan yang telah dipertimbangkan. Entrepreneur merupakan seorang yang mempunyai mental dan semangat entrepreneurship, bermental kuat, mempunyai rasa percaya diri yang tinggi, efisiensi waktu, kreativitas, ketabahan, ulet, kesungguhan, dan bertujuan untuk selalu mempersiapkan pribadi maupun masyarakat agar data hidup layak sebagai manusia, sehingga kehadirannya berdampak positif bagi pengembangan dirinya sendiri, masyarakat, alam dan kehidupan (Nasution, 2001).

Sebagai entrepreneur, belajar dapat dilakukan sendiri sambil praktik (learning by doing), membaca, bertanya, berdiskusi, mencoba, dan sebagainya, terutama untuk halhal aktual yang berkaitan dengan usahanya (Astamoen, 2008). Kemampuan-kemampuan yang perlu diasah antara lain adalah: 1). Kemampuan teknis; seorang entrepreneur perlu memiliki kemampuan memimpin, kemampuan manajemen bisnis dan organisasi, yang didukung oleh kemampuan-kemampuan mendengarkan, serta gaya manajemen yang tepat, baik untuk melatih anak buah, bekerja sebagai anggota tim, maupun untuk bergaul dan membangun jaringan interpersonal. 2). Kemampuan dalam manajemen bisnis; seorang entrepreneur hendaknya memiliki kemampuan perencanaan dan penentuan sasaran yang baik, salah satunya untuk menyusun rencana usaha. 3). Kemampuan pribadi dalam entrepreneur; seorang entrepreneur seyogyanya mampu mengendalikan berdisiplin, tidak gentar mengambil risiko yang diperhitungkan, inovasi dan kreatif, berorientasi pada perubahan, ulet, serta memiliki visi dalam menjalankan usaha dan kehidupannya.

Dari penjelasan di atas dapat disimpulkan bahwa dalam diri peserta didik telah ada potensi berwirausaha atau pengusaha, maka tugasnya pendidik dan pihak pengelola lembaga sekolah untuk mengembangkan potensi tersebut dengan berbagai kesempatan yang dapat diikuti oleh peserta didik dalam membangun masa depannya.

\section{Contoh media pembelajaran berbasis entrepreneurship}

Pelaksanaan kantin jujur di SDN Panggungrejo 04 Kepanjen melibatkan siswa sebagai pelaku pembelajar yang siap dilatih untuk mengasah kemampuan usahanya sebagai entreprener untuk pengalaman di masa depan. Dalam rangka tujuan tersebut maka siswa diberi pengarahan tentang hakikat kantin jujur oleh guru wali kelas masing-masing tingkatan khususnya kelas lima sebagai petugas piket. Harapannya jangka panjang setelah mereka dilatih dalam kegiatan di kantin jujur, itu sebagai pengalaman belajar yang berkesan bagi siswa dan ada keinginan untuk melatih kemandiriannya dalam berwirausaha.

Pengelolaan koperasi sekolah dengan melibatkan siswa-siswi untuk melatih kemandirian, keberanian, tanggung jawab, belajar menanggung resiko, belajar memecahkan masalah.

Kegiatan kepramukaan melatih siswa bagaimana bisa berusaha mandiri dengan wirausaha maupun wiraswasta dalam menjalani hidupnya. 


\section{KESIMPULAN DAN SARAN}

Kemajuan teknologi, budaya bangsa mendorong adanya persaingan global antar negara, kemajuan dalam pendidikan selain memperbaiki SDM juga perangkat pembelajaran sebagai contoh perlu didorong dengan pemanfaatan sumber belajar yang inovatif. Media pembelajaran merupakan alat ataupun sumber belajar yang dapat digunakan untuk mnarik siswa untuk mau belajar dengan senang dan berkesan dalam kehidupan siswa khususnya dalam proses pembelajaran. Pendidikan entrepreneur adalah satu konsep pendidikan yang memberikan semangat pada peserta didik untuk kreatif dan inovatif dalam mengerjakan sesuatu hal. Pola pendidikan sedemikian ini menuntut peserta didik untuk bisa produktif. Pendidikan entrepreneur memberikan kontribusi berupa sebuah alat atau sumber pendidikan yang mengarahkan dan membekali peserta didik untuk bisa lebih cepat dalam merespon perubahan dan memahami kebutuhan sosial ekonomi masyarakat.

Pendidikan entrepreneurship dapat dimaknai sebagai pendidikan calon pengusaha agar memiliki keberanian, kemandirian, serta ketrampilan sehingga meminimalkan kegagalan dalam usaha. Pendidikan entrepreneurship bukanlah pendidikan marketing atau penjualan yang mendidik seseorang untuk jadi pedagang, entrepreneur jauh lebih luas daripada sekedar menjadi penjual. Ada dua karakter seorang entrepreneur. Pertama entrepreneur sebagai creator yaitu menciptakan usaha atau bisnis yang benar-benar baru. Kedua, entrepreneur sebagai innovator, yaitu menggagas pembaruan baik dalam produksi, pemasaran, maupun pengelola dari usaha yang sudah ada sehingga menjadi lebih baik.

\section{DAFTAR PUSTAKA}

Hartatik, 2013. Kajian Kantin Jujur dalam Peningkatkan Pendidikan Karakter untuk Mewujudkan Siswa Kreatif Tingkat Sekolah Dasar (SD) Studi Kasus di SDN Panggungrejo 04 Kepanjen Malang.
Yulianti, 2014. Model dan Perancangan Kantin Jujur Berbasis Entrepreneurship di Tingkat Sekolah Dasar.

Sulistyowati, Endah. 2012. Implementasi Kurikulum Pendidikan Karakter, Yogjakarta: pt. Citra Aji Parama.

Andayati, Dina. 2012. Kantin Kejujuran Berbasis Teknologi Informasi, Jurnal Teknologi Technoscientia ISSN: 19798415 Vol.4 No.2 Februari 2012, hlm.128.

Astamoen, Moko. P. 2008. Entrepreneurship dalam Perspektif Kondisi Bangsa Indonesia, Bandung: Alfabeta.

Komaruddin, 2000. Kamus Istilah Karya Tulis Ilmiah. Jakarta: Bumi Aksara.

Sagala, Syaiful. 2010. Konsep dan Makna Pembelajaran, Bandung: PT. Alfabeta. 